\title{
THE INFLUENCE OF THE ANTARCTIC CIRCUMPOLAR CURRENT ON THE OCEANOGRAPHIC SETTING OF A SUB-ANTARCTIC ISLAND
}

\author{
by Isabelle J. Ansorge and J. R. E. Lutjeharms
}

(with five text-figures)

\author{
Ansorge, I.J. \& Lutjeharms, J.R.E. 2007 (23:xi): The influence of the Antarctic Circumpolar Current on the oceanographic setting of \\ a sub-Antarctic island. Papers and Proceedings of the Royal Society of Tasmania 141(1): 59-66. \\ https://doi.org/T•.26749/rstpp.T4T.T.59 ISSN 008-4703. Department of Oceanography, University of Cape Town, \\ Rondebosch 7701, South Africa (IJA*, JREL). *Author for correspondence.
}

\begin{abstract}
The circulation in the Southern Ocean is dominated by the Antarctic Circumpolar Current (ACC), which is the only current that flows completely around the globe. The ACC is a complex system consisting of narrow regions of sharp horizontal density gradients, which extend through the entire water column as frontal bands separated by broad zones with less intense gradients. Meridional excursions from the otherwise zonal flow in the form of meanders or mesoscale eddies occur in regions of prominent bathymetric features, suggesting a close relationship between the level of mesoscale sea surface variability and bottom topography. The Prince Edward Islands (Marion Island and Prince Edward Island) lying within the Polar Frontal Zone (PFZ) at approximately $38^{\circ} \mathrm{E}, 47^{\circ} \mathrm{S}$ form a very special terrestrial habitat and have, for this reason, been designated a declared nature reserve. The ecology of the islands is directly dependent on its ocean environment. With the advent of satellite altimetry it has become apparent that the Prince Edward Islands are located on the northern border of a region of remarkably high mesoscale variability. The source of this variability lies where the current jet associated wirh the ACC intersects the South West Indian Ridge. From here newly generated eddies are steered by the bottom topography past the Prince Edward Islands. This discovery probably explains the high physical and biological variability found at the islands, and warrants further analysis.
\end{abstract}

Key Words: Prince Edward Islands, Antarctic Circumpolar Current, meanders, mesoscale eddies.

\section{INTRODUCTION}

The Southern Ocean is the oceanic region that surrounds the entire Antarctic continent, and consists of the southern extents of the Atlantic, Indian and Pacific oceans (fig. 1). The Antarctic continent forms its southern boundary, and while the northern border is not physiographically fixed, it is usually considered to coincide with the location of the Subtropical Convergence (Lutjeharms 1985). The unique geography of the Southern Ocean makes it the only place where ocean currents run completely around the globe. Dominating the region is the strong, deep, eastward-flowing Antarctic Circumpolar Current (ACC) - often referred to as the "West Wind Drift" after the strong westerly winds that prevail between $40^{\circ} \mathrm{S}$ and $60^{\circ} \mathrm{S}$ sandwiched between the subtropical high pressure belt in the north and the Antarctic trough, which lies south of $65^{\circ} \mathrm{S}$ (Taylor et al. 1978).

The Southern Ocean plays a major role in global ocean circulation and, in particular, on present-day climate. Extending unbroken around Antarctica, the ACC, is by far the largest conduit by which water, heat and salt are transferred between different ocean basins (fig. 1). As these exchanges play an important role in regulating mean global climate, a better understanding of the physical and dynamic processes, which are responsible for the variability of the ACC, is highly important (Budillon \& Rintoul 2003). The surface flow of the ACC is driven primarily by the frictional stress of the westerly wind. Combined with the Coriolis force, a northward component to the surface current is responsible for the formation of frontal bands, which act as boundaries separating zones of uniform water mass. These fronts are a distinct permanent feature in the Southern Ocean. They are circumpolar but show a strong temporal and spatial variability in different oceanic sectors (Lutjeharms 1985). Their positions are mainly determined by topographic steering of the ACC (Gordon et al. 1978) in combination with the global spatial pattern of wind fields, in particular the distribution of the wind stress curl (Nowlin \& Clifford 1982). Transects across the ACC show this current to consist of zones of several quasi-uniform water masses separated by fronts in which horizontal gradients of properties are relatively large. These broad

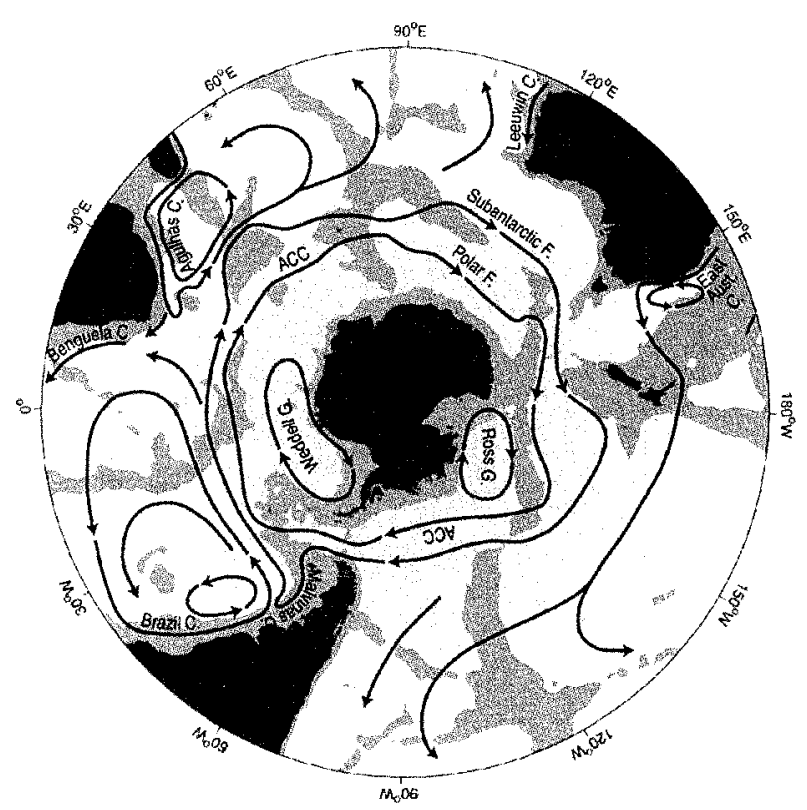

FIG. 1 - Schematic map of the major currents in the Southern Hemisphere south of $20^{\circ} \mathrm{S}$. Depths shallower than $3500 \mathrm{~m}$ are shaded. The two main cores of the Antarctic Circumpolar Current are shown - the Sub-Antarctic Front (SAF) and the Antarctic Polar Front (APF). The interbasin exchange between the Southern, Pacific, Atlantic and Indian oceans is clearly shown (afier Rintoul et al. 2001). 
zones are (from north to south) the Sub-Antarctic Zone, Polar Frontal Zone, Antarctic Zone and the Continental Zone (Whitworth 1980). They are demarcated by the major circumpolar fronts of the ACC; respectively the Subtropical Convergence, Sub-Antarctic Front, Antarctic Polar Front and the Southern Antarctic Circumpolar Front (Lutjeharms \& Valentine 1984, Whitworth \& Nowlin 1987).

\section{SUBTROPICAL CONVERGENCE}

The Subtropical Convergence (STC) marks the boundary between warm, salty subtropical surface water to the north and cooler, fresher sub-Antarctic Surface Water to the south (fig. 2). It is the most prominent surface thermal front with surface remperatures ranging from $10.3-16.9^{\circ} \mathrm{C}$ (Belkin $\&$ Gordon 1996). Its mean position lies at $41^{\circ} 40^{\prime} \mathrm{S}$ (Lutjeharms 1985). In the western part of the Indian sector it is one of the strongest fronts in the world ocean (Lutjeharms 1985). In this region, the extension of the Agulhas Current, the Agulhas Return Current (Lutjeharms \& Ansorge 2001), strengthens the horizontal gradients of this front considerably leading to the formation of intense mesoscale eddies. These heat anomalies have been shown to have a marked influence on the overlying atmosphere and on local biota (Llido et al. 2005). Recent investigations at the STC, using both satellite remote sensing as well as modelling (Llido et al. 2005), have demonstrated the climatological importance here of primary production. It has been shown that primary production at this front occurs as event-scale blooms and not as persistent enhancement as was suggested previously (Weeks \& Shillington 1996).

\section{SUB-ANTARCTIC FRONT}

The sub-Antarctic Front (SAF) represents the northern boundary of the Polar Frontal Zone (PFZ) and marks the southern extent of sub-Antarctic Surface Water. In comparison to the STC, which is clearly characterised by a sharp and consistent gradient in both surface and subsurface expressions, making identification extremely easy (Lutjeharms \& Valentine 1984), the SAF is less clear in its surface expression. The exact boundaries of the PFZ can therefore be difficult to identify due to the weak nature of this front. The SAF is predominantly a subsurface front and can be defined by the most vertically orientated isotherm within a temperature gradient lying between $3^{\circ} \mathrm{C}$ and $5^{\circ} \mathrm{C}$, while its surface expression extends between $8^{\circ} \mathrm{C}$ and $4^{\circ} \mathrm{C}$. As the surface expression is generally weak, the subsurface structure with the $6^{\circ} \mathrm{C}$ isotherm as its core is usually the preferred indicator. Despite its ill-defined surface expression, recent investigations (Swart et al. $\mathrm{ms}$ ) have found that the SAF contributes over $30 \%$ to the volume flux of the ACC. The subsurface SAF axial indices remain fairly stable lying at a mean location of $47^{\circ} 25^{\prime} \mathrm{S}$ (Lutjeharms \& Valentine 1984, fig. 2).

\section{ANTARCTIC POLAR FRONT}

The Antarctic Polar Front (APF) or Antarctic Convergence marks the northern limit of the Antarctic Zone where Antarctic Surface Water moving northwards sinks below warmer sub-Antarctic water masses. The APF is a region of elevated current speeds and strong horizontal gradients in density, temperature and salinity (Deacon 1937, 1983). The

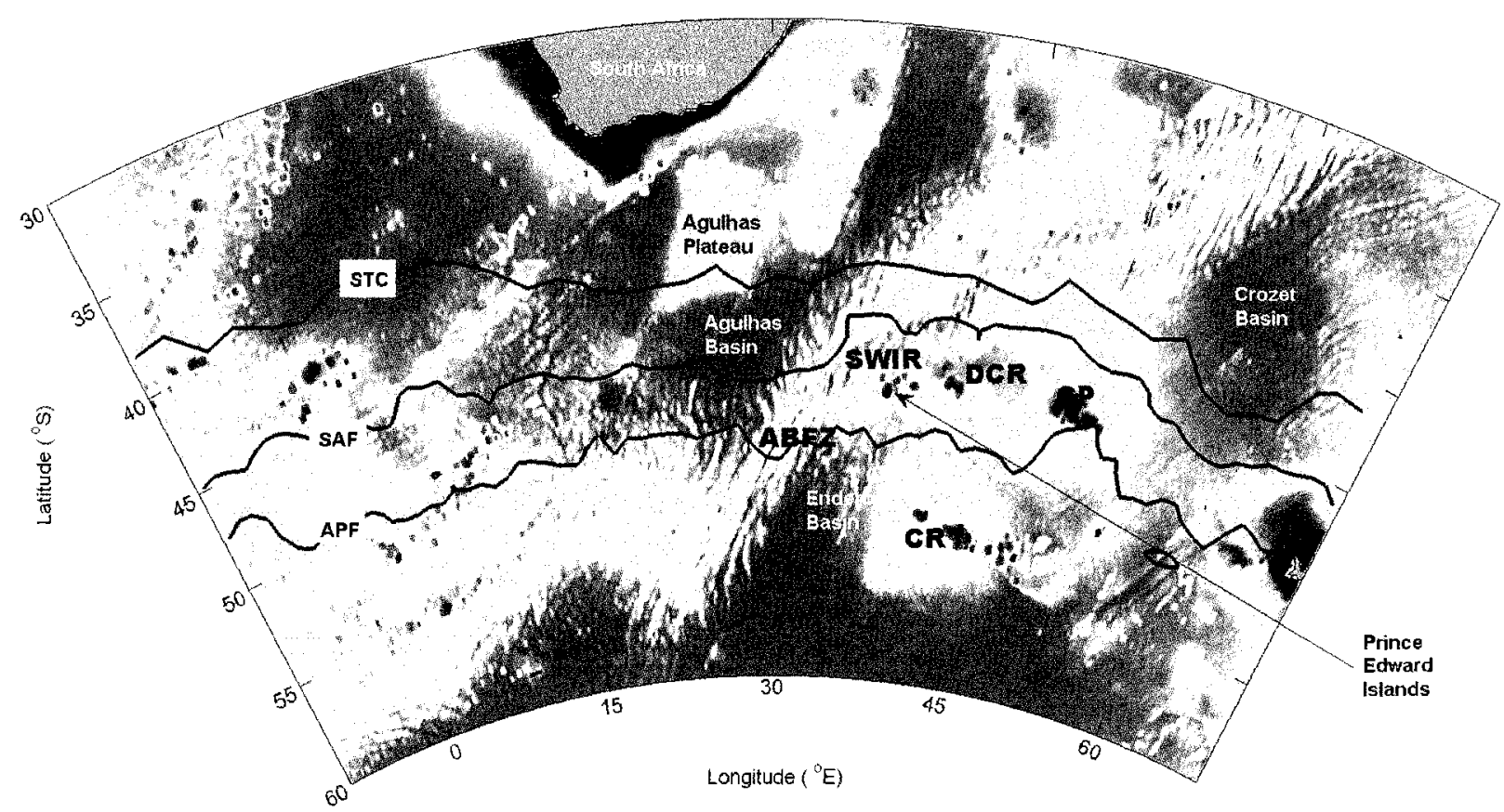

FIG. 2 - Schematic showing the locations of the subsurface expressions of the Sub-Antarctic, Antarctic Polar Fronts and the Subtropical Convergence in the eastern Atlantic and western Indian Ocean sectors of the Southern Ocean. SWIR denotes the Soush-West Indian Ridge, $A B F Z=$ Andrew Bain Fracture Zone, DCR $=$ Del Cano Rise, $C P=$ Crozet Plateau and CR $=$ Conrad Rise. The location of the Prince Edward Islands is clearly shown. 
subsurface expression of the APF historically is identified by the northern limit of the $2^{\circ} \mathrm{C}$ temperature minimum at a depth of $200 \mathrm{~m}$ (Whitworth 1980). However, the surface and subsurface expressions do not always coincide and are often approximately $50 \mathrm{~km}$ apart (Lutjeharms \& Valentine 1984). In these instances the surface expression can be identified by the maximum temperature gradient between $6^{\circ} \mathrm{C}$ and $2^{\circ} \mathrm{C}$. The APF can be further characterised by a shallow temperature minimum associated with the remnants of Winter Water, which lies at depths between 50 and $150 \mathrm{~m}$. It is seasonally variable; in winter it is nearly homogenous extending to $250 \mathrm{~m}$, while in summer the mixed layer extends only to between 50 and $100 \mathrm{~m}$. Surface sea temperatures range from $-1.8^{\circ}$ to $6^{\circ} \mathrm{C}$ at the APF. The APF has a mean location of between $52^{\circ} \mathrm{S}$ and $53^{\circ} \mathrm{S}$ (Orsi et al. 1995, fig. 2).

Current measurements at the Drake Passage have shown the ACC to include an additional frontal feature south of the APF, called the Southern Antarctic Circumpolar Current Front (Orsi et al. 1995), corresponding to the position of the atmospheric low-pressure belt known as the Antarctic trough (Taylor et al. 1978).

In this paper we present an overview of the ocean variability in the Southern Ocean, in particular the influence prominent bathymetry may have on ocean circulation. Using the sub-Antarctic Prince Edward Islands as a case study, we highlight how changes in the flow of the ACC brought on by topographical steering and eddy generation have a marked effect on the ocean environment of these islands as well as on the local distribution of biota (Bernard et al. 2007)

\section{VARIABILITY IN THE SOUTHERN OCEAN}

Extensive investigations have been carried out in the past decades to understand the flow pattern of the ACC and the extent of its temporal and spatial variability throughout the Southern Ocean. A good correspondence between the increased surface speeds of the ACC and the locations of the three main fronts - the STC, SAF and APF - seems to exist (Hofmann 1985). A banded current structure clearly occurs within the ACC. Meridional excursions from the otherwise zonal flow in the form of meanders or mesoscale eddies occur in regions of prominent bathymetric features, suggesting a close relationship between the degree of mesoscale sea surface variability and bottom topography (fig. 3). Indeed, global charts of sea surface height anomalies in the world's oceans (Nerem et al. 1994) show certain persistent patterns in the Southern Ocean, with regions of high mesoscale variability correlating closely where the ACC interacts with prominent bottom topography such as the South-West Indian Ridge, Crozet and Kerguelen Plateaux and the Macquarie Ridge or at choke points such as the Drake Passage (fig. 3). The importance these regional "eddy hotspots" have in influencing exchange between the Southern Ocean and adjacent ocean basins is currently the focus of many projects. This interbasin exchange provides an important link in the meridional heat and salt fluxes that balance much of the ocean-atmosphere exchange. It has been suggested by de Szoeke \& Levine (1981) that the meridional heat flux required to balance the heat lost through air-sea exchange in the Southern Ocean may be accomplished by the cross-frontal advection of mesoscale eddies. Indeed, direct measurements of regions of high variability near the Drake Passage (Johnson \& Bryden 1989), South-West Indian Ridge (Ansorge et al. 2006) south of Tasmania (Phillips \& Rintoul 2000) and south of New Zealand (Bryden \& Heath 1985), as well as numerical model estimates (Jayne \& Marotzke 2002) show consistent eddy heat fluxes across the ACC with values ranging between $11.3 \mathrm{kWm}^{-2}$ and $15.4 \mathrm{kWm}^{-2}$. Furthermore, these studies have shown that cold eddies exhibit a negative heat and salt anomaly relative to the ambient waters by transporting cool, low salinity, polar water northwards across the APF into the PFZ, while warm eddies offer the reverse with a positive heat and salt anomaly by their transport of warm, saline water masses southwards. The geographic distribution of such eddies is, however, very inhomogeneous. One such region that stands out as such an "eddy hotspot" is the South-West Indian Ridge centred at $30^{\circ} \mathrm{E}, 50^{\circ} \mathrm{S}$ (fig. 3).

\section{A CASE STUDY - THE PRINCE EDWARD ISLANDS}

Sub-Antarctic islands such as the Prince Edward Islands (Marion Island and Prince Edward Island) are classified as isolated, hostile, impoverished regions, in which the terrestrial and marine ecosystems are relatively simple and extremely sensitive to perturbations. They provide an ideal ecological laboratory for studying how organisms, ecological processes and ecosystems respond to a changing climate in the Southern Ocean (Smith 2002). Furthermore, these islands are seasonally characterised by enormous populations of top predators and subsequently any changes in the frontal dynamics, either in the vicinity of these islands or further afield, may have strong implications on their foraging behaviour as already shown from studies on the Grey-headed Albatrosses (Thalassarche chrysostoma (Forster, 1785)) (Nel et al. 2001).

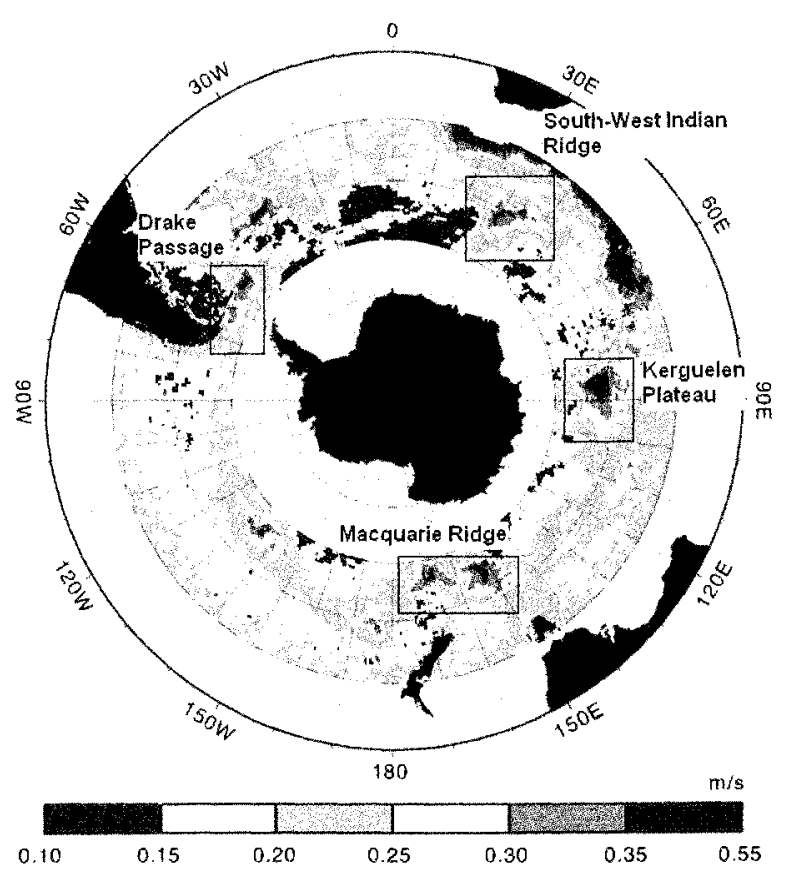

FIG. 3-Distribution of areas with high levels of Eddy Kinetic Energy in the Southern Ocean (after Gille et al. 2000). The regions of high variability are shown in red. One area of interest can be found at $50^{\circ} \mathrm{S}, 30^{\circ} \mathrm{E}$ and relates to the high variability associated with the South-West Indian Ridge. 
As a consequence, the Prince Edward Islands can be considered as biodiversity hot spots within the Southern Ocean. The energy necessary to sustain such large numbers of top predators is derived from the close interaction between the oceanic environment and the islands themselves. Changes in the intensity and geographic position within these frontal systems are likely to coincide with dramatic changes in the distribution of species and total productivity within the Southern Ocean.

The South-West Indian Ridge extends from the southwest to the northeast and lies to the immediate west of the Prince Edward Islands. As in the case of all mid-ocean ridges it is criss-crossed by fracture zones (figs 2, 4), such as the Andrew Bain fracture zone at $50^{\circ} \mathrm{S}, 30^{\circ} \mathrm{E}$. The Prince Edward Islands lie directly east of the South-West Indian Ridge on a distinct and independent pinnacle that rises from about $5000 \mathrm{~m}$ depth. This is particularly clear to the south, whereas to the north it is somewhat complicated by other seamounts that do not break the sea surface. To the northeast lies an extensive shallow feature, the Crozet Plateau. A large part of this zonal rise is shallower than $2000 \mathrm{~m}$. Îles Crozet lie on its easternmost extremity. It is clear that this complex pattern of ridges and rises (fig. 2) forms important restrictions to the flow of the ACC resulting in enhanced variability (fig. 3). Hydrographic data collected during the South-West Indian Ocean Experiment in 1993 and 1995 (Pollard \& Read 2001) have shown that close to the South-West Indian Ridge the ACC splits, and further to the east there appears to be a distinct separation in these branches with the SAF deflected northeastwards, thus widening the PFZ by up to $5^{\circ}$ of latitude. Modelling results (Craneguy \& Park 1999) have also indicated that the position of the SAF and APF, and thus the degree of variability, are dependent on the velocity at which the ACC approaches the South-West Indian Ridge.

Extensive XBT (Expendable Bathythermograph) surveys between South Africa and the Prince Edward islands have shown that these islands $\left(47^{\circ} \mathrm{S}, 37^{\circ} \mathrm{E}\right)$ are located within the core of the ACC, sandwiched between the SAF to the north and the APF to the south (fig. 2) (Lutjeharms
1985). These fronts separate sub-Antarctic Surface Water from Antarctic Surface Water, with a zone of transition known as the PFZ between the two (in which sub-Antarctic Surface Water gradually modifies, becoming cooler and fresher to form Antarctic Surface Water). The SAF and APF demonstrate a high degree of latitudinal variability in this region (Lutjeharms \& Valentine 1984). Deacon (1987) has postulated that the complexity of the ACC in the vicinity of the Prince Edward Islands results in an increase in the interchange of Antarctic and sub-Antarctic Surface Water within the PFZ here. Furthermore, sea surface temperature data suggest that these islands may be influenced by the intermittent passage of both warm and cold core eddies from further upstream (Ansorge \& Lutjeharms 2003, 2005 , Ansorge et al. 2006).

The clear implication of this behaviour is that the Prince Edward Island region has an enhanced anomaly presence not so much because of the interaction of the flow with the islands themselves, as has been inferred previously (Ansorge et al. 1999, Ansorge \& Lutjeharms 2003), but as a consequence of the fact that they are situated at the northern border of this region of unusually high mesoscale variability in the Southern Ocean (fig. 3). Indeed, previous investigations have shown that eddies generated at this ridge move northeastwards over a period of 11 months in a narrow corridor between $48-49^{\circ} \mathrm{S}$ and $34-38^{\circ} \mathrm{E}$ before dissipating (fig. 4) (Ansorge \& Lutjeharms 2003, Ansorge et al. 2006). None of these eddies to date have been observed east of $45^{\circ} \mathrm{E}$ indicating that their anomalous heat and salt content are usually mixed out over this distance. A time-series of sea surface height anomalies within the eddy corridor $\left(48^{\circ} 30^{\prime} \mathrm{S}\right.$ and $\left.35^{\circ} \mathrm{E}\right)$, for 2002-2006, shows that on average five eddies pass through this point per year. A well-studied example of a cold eddy observed in 2005 was illustrated by Ansorge et al. (2006, fig. 5) in the lee of the South-West Indian Ridge between $48^{\circ}-49^{\circ} 15^{\prime} \mathrm{S}$ and $33^{\circ}-36^{\circ} \mathrm{E}$. Its rotation was cyclonic with speeds exceeding $0.6-1.3 \mathrm{~ms}^{-1}$ at the southeast and northwest boundaries and approximately $0.15-0.25 \mathrm{~ms}^{-1}$ within its core. The feature exhibited a steep shoaling of isotherms (fig. 5) and

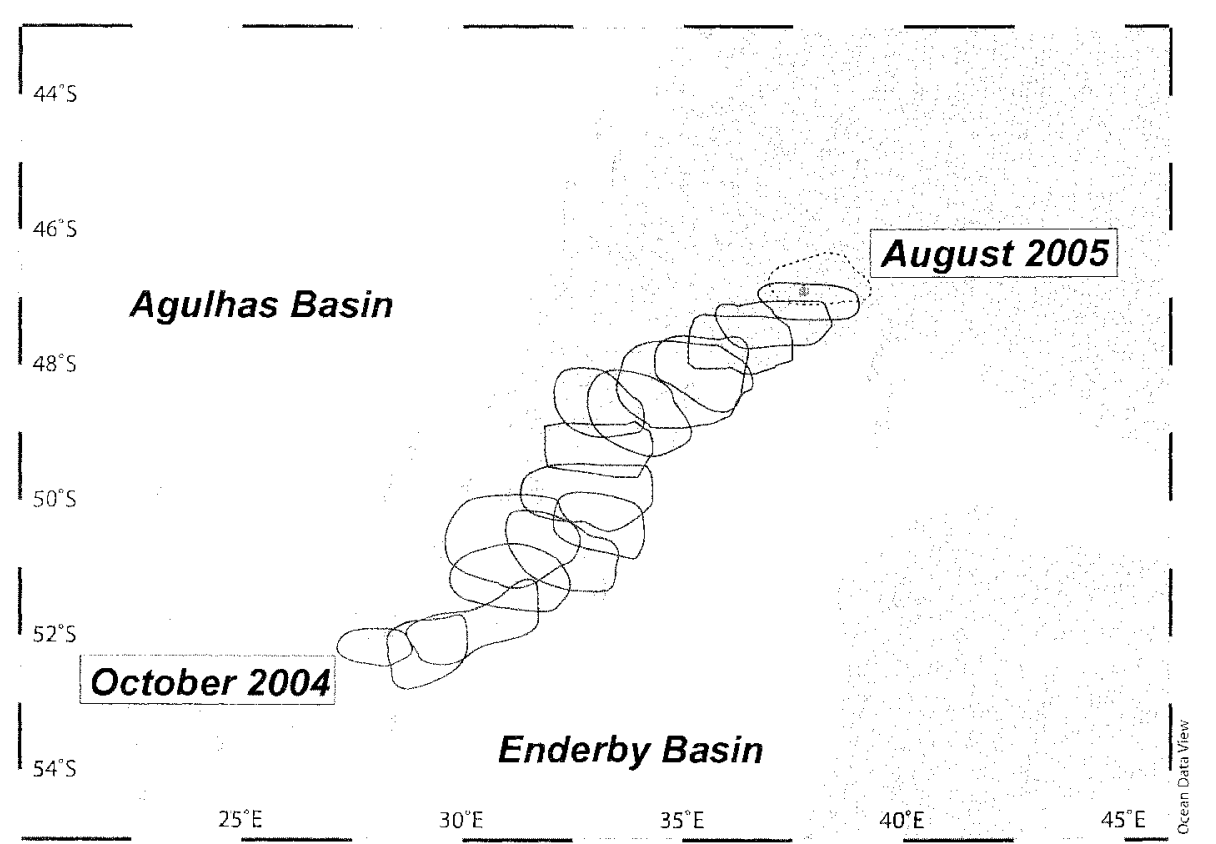

FIG. 4 - The northeastward translation of the cold eddy from the South-West Indian Ridge to the vicinity of the Prince Edward islands at approximately $47^{\circ} S, 38^{\circ} \mathrm{E}$ (after Ansorge et al. 2006). Temporal intervals between locations are between 10 and 30 days. The $4000 \mathrm{~m}$ isobath highlighting the location of the South-West Indian Ridge in relation to the passage of the cold eddy has been shaded. 
isohalines characteristic of a cold eddy. Typical upper-layer profiles of temperature across the cold eddy show a welldeveloped subsurface temperature minimum layer $\left(\mathrm{T}_{\min }=\right.$ $<0.5^{\circ} \mathrm{C}$ ), which is capped in the top $100 \mathrm{~m}$ by a relatively warm $>4.2^{\circ} \mathrm{C}$ surface layer (fig. 5). Observations south of Australia (Morrow et al. 2004) have shown that cold eddies following detachment from the APF quickly lose their sea surface temperature signature as a result of summer warming of the surface layers. Consequently the subsurface layer provides a better indicator of eddy origin.

A horizontal section through the eddy at a depth of $200 \mathrm{~m}$ gives its dimensions and demonstrates the contrast between the temperature of its core waters and that of the surrounding waters. The core of the eddy had temperatures of $<1^{\circ} \mathrm{C}$ whereas the surrounding water was warmer than $3^{\circ} \mathrm{C}$ and corresponding salinity values between 34.121-34.135 are indicative of Antarctic water masses within its core. The eddy was not entirely circular, but had a mean diameter of about $220 \mathrm{~km}$. This, and satellite altimetry, shows unambiguously that its waters had their origin south of the APF. This is also evident from a vertical hydrographic section through the eddy (fig. 5). The observed temperatures to a depth of $920 \mathrm{~m}$ demonstrate the sharp distinction of waters in the eddy and those outside it. This was when the eddy was still fairly young and had not undergone much mixing with its environment.

The temperature minimum at roughly $240 \mathrm{~m}$ depth (fig. 5) is characterised by Antarctic Winter Water still intact so shortly after the eddy had formed. The thermohaline structure of Antarctic Winter Water is determined by seasonally changing air-sea interactions such as air-sea fluxes of momentum, heat, freshwater as well as the advection, formation and melting of sea ice (Park et al. 1998). In winter it is nearly homogenous extending to $250 \mathrm{~m}$, while in summer the mixed layer extends only between 50 and $100 \mathrm{~m}$. Temperature ranges are large, from $-1.8^{\circ} \mathrm{C}$ to $6^{\circ} \mathrm{C}$ at the APF, and salinity from 33.4-34.2. The close relationship with changing atmospheric conditions provides a unique imprint on the structure and character of Antarctic Surface Water and thus the random transport of this water mass across the APF by mesoscale eddies must be considered in understanding better regional climatic variability. At the base of the Antarctic Surface Water (AASW) lies Circumpolar Deep Water (CDW) characterised by relatively warm, salty and low-oxygenated waters. The most unambiguous demarcation between the AASW and the CDW is the strong oxygen gradient associated with a rapid decrease in oxygen concentration (Park et al. 1998), separating the highly oxygenated AASW ( $>7 \mathrm{ml} \mathrm{l}^{-1}$ ) from the oxygen-poor CDW $\left(<4 \mathrm{ml} \mathrm{l}^{-1}\right)$. Furthermore, a vertical salinity section across the eddy clearly shows a distinct shoaling of isohalines. Salinities increased with depth (34.20-34.68) with $>34.3$ observed below $380 \mathrm{~m}$ within the core of the eddy further suggesting the presence of CDW.

The eddy was first observed in satellite altimetry in October 2004 and by August 2005 had sufficiently dissipated that it was no longer observable as a distinct sea surface height anomaly (fig. 4). This lifetime of less than a year is typical

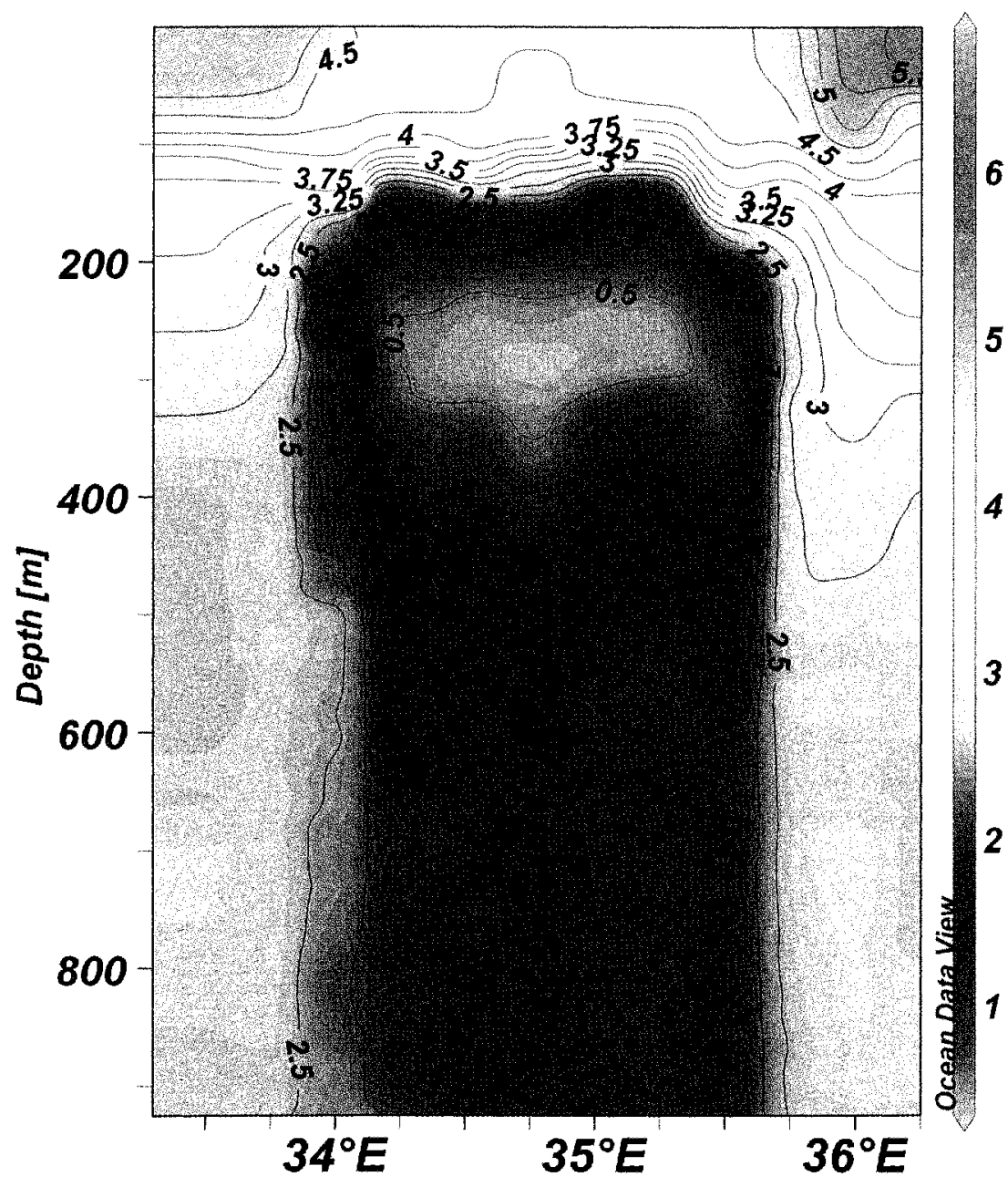

FIG. 5 - Vertical temperature section

1 across a cold core eddy, which was observed in April-May 2005. 
for this type of eddy. The introduction and, consequently, dispersal of an insular volume of a pure Antarctic water mass into the PFZ by a cold eddy may play an important role in the meridional biological flux across the ACC (Bernard et al. 2007). A regular supply of these eddy types will therefore influence the foraging behaviour of the top predators, resulting in potential important impacts on the ecosystem of the Prince Edward Islands (Nel et al. 2001).

The view that the ocean region around the Prince Edward Islands represents a transition zone between the warmer subAntarctic waters to the north and colder Antarctic Surface Waters to the south is reflected in the euphausiid species composition within the region, with species subtropical, sub-Antarctic and Antarctic in origin co-occurring at any one time (Gurney et al. 2002). A number of previous studies (Endo \& Wiebe 2005, Mackas et al. 2005) have demonstrated that the zooplankton community associated with eddies is distinguishable from the surrounding waters. The euphausiids observed outside the cold eddy in the PFZ waters were typical of this region (Pakhomov \& Froneman 2000, Froneman et al. 2002, Gurney et al. 2002). In contrast, the euphausiids sampled within the core region comprised mainly vagrants (Euphausia triacantha and E. frigida) that are rarely recorded within the PFZ (Pakhomov \& Froneman 2000; Gurney et al. 2002), and are typically associated with Antarctic water masses found south of the APF (Mauchline \& Fisher 1969). It is possible that the zooplankton found in the core of an eddy reflect the area where the eddy has been spawned. The presence of Antarctic species suggests that the eddy, formed south of the APF, was able to retain and transport the euphausiid species that were distinctive of the front. However, despite the potentially important rote the complexity of the PFZ may play in the island ecosystem, few studies have been conducted in the region of the South-West Indian Ridge. Further investigations need to address what implications this unusual eddy street has on the marine ecosystem of the Prince Edward islands.

The PFZ is characterised as a transitional region in which warm, salty sub-Antarctic water masses are gradually modified with distance south. In addition, it has been shown that the PFZ forms a primary sink for the formation of SubAntarctic Mode Water (SAMW) and Antarctic Intermediate Water masses (AAIW). Identified as a salinity minimum in the water column, these water masses mark the base of thermocline ventilation into the Southern Hemisphere and form a major source of freshwater input into the world oceans. The consistency with which these water masses are formed and exported is vital in maintaining the freshwater budget and thus the thermohaline overturning of the world's oceans. The introduction of an insular volume of a pure Antarctic water mass into the PFZ by a cold eddy may play an important role in the meridional biological flux across the ACC. Traditionally the northward transport of Antarctic water masses across the ACC has been attributed to Eckman transport; however, the cross-frontal advection of cold eddies from the AAZ into the PFZ may in fact play a central role in altering the physical-chemical characteristic of this region (Sloyan \& Rintoul 2001).

Despite the importance of these processes, variations in cross-frontal eddy exchange and their contribution to the formation or modification of SAMW remains one of the most poorly observed quantities in the Southern Ocean and coarse resolution climate models do not accurately resolve the transport associated with these features neither do they resolve the implications these isolated bodies of water have on the local ecosystem. Such changes in the character of the PFZ forced by the introduction of cold, fresh Antarctic water masses could dramatically affect the productivity of this region.

\section{CONCLUSION}

The meridional heat fluxes in the Southern Ocean are a key component for the accurate simulation of the global ocean circulation in models and in our ability to understand better interannual and decadal changes occurring in the Southern Ocean. If the assumption is correct that the greater part of this flux comes about through mesoscale eddies, then the quantification of the fluxes at those regions where the mesoscale turbulence is highest (fig. 3) may well be crucial. These eddy fluxes may, however, be very sensitive to changes in the velocity and position of the ACC. Furthermore, subsurface observations have shown an increase of $0.17 \mathrm{C}^{\circ}$ since 1950 in the Southern Ocean, possibly brought on by a southward shift in the position of the ACC (Gille 2002). Consequently, shifts in the position of the main frontal bands associated with the ACC may possibly affect and influence the efficiency with which eddies are generated at eddy pumping regions, such as the South-West Indian Ridge. Recent studies have shown that once formed such eddies advect northeastwards in to the vicinity of the Prince Edward Islands (fig. 4) before gradually spinning down within the PFZ (Ansorge \& Lutjeharms 2005, Ansorge et al. 2006), The precise role of these eddies in the local marine and island ecology needs focused research. It seems possible that the ecosystem of the Prince Edward Islands benefits substantially from its location in the vicinity of the eddy street originating at the South-West Indian Ridge. Indeed, these eddies carry with them organisms from their region of origin suggesting that the surrounding waters of the Prince Edward Islands have a much more diverse spectrum of biota than one would normally expect from an island in the sub-Antarctic (Bernard et al. 2007). Moreover, these and other eddies create unusual habitats of their own, particularly at their borders. This has become evident from the feeding behaviour of some birds ( $\mathrm{Nel}$ et al. 2001). The further study of this mechanism and its implications is being planned.

\section{ACKNOWLEDGEMENTS}

This research was funded by the South African National Antarctic Programme, Department of Environmental Affairs and Tourism, the National Research Foundation, University of Cape Town and Rhodes University. We are grateful to students as well as the complement of the S.A. Agulhas for their enthusiastic help. Dr Ansorge is also grateful to the Sub-Antarctic Forum for providing partial funds to attend this meeting in Tasmania in 2006. The authors thank J.V. Durgadoo for the use of figure 2.

\section{REFERENCES}

Ansorge, I.J., Froneman, P.W., Pakhomov, E.A., Lutjeharms, J.R.E., Perissinotto, R. \&. van Ballegooyen, R.C. 1999: Physical-biological coupling in the waters surrounding the Prince Edward Islands (Southern Ocean). Polar Biology 21: $135-145$. 
Ansorge, I.J. \& Lutjeharms, J.R.E. 2003: Eddies originating from the South-West Indian Ridge. Joumal of Marine Systems 39: 1-18.

Ansorge, I.J. \& Lutjeharms, J.R.E. 2005: Direct observations of eddy turbulence at a ridge in the Southern Ocean. Geophysical Research Letters 32: doi:10.1029/2005GL022588.

Ansorge, I.J., Lutjeharms, J.R.E., Swart, N.C. \& Durgadoo, J.V. 2006: Observational evidence for a cross-frontal heat pump in the Southern Ocean. Geophysical Research Letters 33: L19601, doi:10.1029/2006GL026174.

Belkin, I. M. \&. Gordon, A.L. 1996: Southern Ocean fronts from the Greenwich meridian to Tasmania. Journal of Geophysical Research 101(C2): 3675-3696.

Bernard, A.T.F., Ansorge, I.J., Froneman, P.W., Lutjeharms, J.R.E. \& Bernard, K.S. 2007: Entrainment of Antarctic euphausiids across the Antarctic Polar Front by a cold eddy. Deep-Sea Research I (in press).

Bryden, H.L. \& Heath, R.A. 1985: Energetic eddies at the northern edge of the Antarctic Circumpolar Current in the southwest Pacific. Progress in Physical Oceanography 14: $65-87$.

Budillon, G. \& Rintoul, S.R. 2003: Fronts and upper ocean thermal variability south of New Zealand. Antarctic Science 15: 141-152.

Craneguy, P. \& Park, Y.-H. 1999: Contrôle topographique de courant circumpolaire antarctique dans l'océan Indien sud. Comte Rendu Académie des Sciences, Sciences de la terre et de planetes 328: 583-589.

Deacon, G.E.R. 1937: The hydrology of the Southern Ocean. Discovery Reports 15: 1-24.

Deacon, G.E.R. 1983: Physical and biological zonation in the Southern Ocean. Deep-Sea Research 29: 1, 1-15.

de Szoeke, R. \& Levine, M. 1981: The advective flux of heat by mean geostrophic motions in the Southern Ocean. Deep-Sea Research 28: 1057-1085.

Endo, Y. \& Wiebe, P.H. 2005: Euphausiid distribution, abundance and succession in a North Atlantic warm-core ring 82B. Journal of Plankton Research 27: 175-188.

Froneman, P.W., Pakhomov, E.A., Gurney, L.J. \& Hunt, B.P.V. 2002: Predation impact of carnivorous macrozooplankton in the vicinity of the Prince Edward Island archipelago (Southern Ocean) in austral autumn 1988. Deep-Sea Research II 49: 3243-3254.

Gille, S.T. 2002: Warming of the Southern Ocean since the 1950 s. Science 295: 1275-1277.

Gille, S.T., Yale, M.M. \& Sandwell, D.T. 2000: Global correlation of mesoscale ocean variability with seafloor toughness from satellite altimetry. Geophysical Research Letters 27: 1251-1254.

Gordon, A.L., Molinelli, E. \& Baker, T. 1978: Large scale relative dynamic topography of the Southern Ocean. Journal of Geophysical Research 83: 3023-3032.

Gurney, L.J., Froneman, P.W., Pakhomov, E.A. \& McQuaid, C.D. 2002: Diel feeding patterns and daily ration estimates of three sub-Antarctic euphausiids in the vicinity of the Prince Edward Islands (Southern Ocean). Deep-Sea Research II 49: 3207-3227.

Hofmann, E.E. 1985: The large scale horizontal structure of the Antarctic Circumpolar Current from FGGE drifters. Journal of Geophysical Research 90: 7087-7097.

Jayne, S.R. \& Marotzke, J. 2002: The oceanic eddy heat transport. Journal of Physical Oceanography 32: 3328-3345.

Johnson, G.C. \& Bryden, H.L. 1989: On the size of the Antarctic Circumpolar Current. Deep-Sea Research I 36: 39-53.

Llido, J., Garçon, V., Lutjeharms, J.R.E. \& Sudre, J. 2005: Event-scale blooms drive enhanced primary productivity at the Subtropical Convergence. Geophysical Research Letters 32,15: L5611, doi. 10.1029/2005GL022880.

Lutjeharms, J.R.E. \& Valentine, H.R. 1984: Southern Ocean thermal fronts south of Africa. Deep-Sea Research 31,12: $1461-1476$.
Lutjeharms, J.R.E. 1985: Location of frontal systems between Africa and Antarctica: some preliminary results. Deep-Sea Research 32,12: 1499-1509.

Lutjeharms, J.R.E. \& Ansorge, I.J. 2001: The structure and transport of the Agulhas Return Current between South Africa and $70^{\circ} \mathrm{E}$. Journal of Marine Systems 30: 115-138.

Mackas, D.L., Tsurumi, M., Galbraith, M.D. \& Yelland, D.R. 2005: Zooplankton distribution dynamics in a North Pacific eddy of coastal origin: II mechanisms of eddy colonisation by and retention of offshore species. Deep-Sea Research II 52: 1011-1035.

Mauchline, J. \& Fisher, L.R. 1969: The biology of euphausiids. In Russell, F.S. \& Yonge, M. (eds): Advances in Marine Biology 7. Academic Press, New York: pp. 1-454.

Morrow, R., Donguy, J.R., Chaigneau, A. \& Rintoul, S.R. 2004: Cold-core anomalies at the sub-Antarctic front, south of Tasmania. Deep Sea Research 51: 1417-1440.

Nel, D.C., Lutjeharms, J.R.E., Pakhomov, E.A., Ansorge, I.J., Ryan, P.G. \& Klages, N.T.W. 2001: Exploiration of mesoscale oceanographic features by grey-headed albatrosses Thalassarche chrysostoma in the southern Indian Ocean. Marine Ecology Progress Series 217: 15-26.

Nerem, R.S., Schrama, E.J.,Koblinsky, C.J. \& Beckley, B.D. 1994: A preliminary evaluation of ocean topography from the TOPEX/Poseidon mission. Journal of Geophysical Research 99: 24565-24583.

Nowlin, W.D. \& Clifford, M. 1982: The kinematic and thermohaline zonation of the Antarctic Circumpolar Current at the Drake Passage. Journal of Marine Research 40: $481-507$

Orsi, A.H., Whitworth, T. \&. Nowlin, W.D. 1995: On the meridional extent and fronts of the Antarctic Circumpolar Current. Deep-Sea Research I 42: 641-673.

Pakhomov, E.A \& Froneman, P.W. 2000: Composition and spatial variability of macroplankton and micronekton within the Antarctic Polar Frontal Zone on the Indian Ocean during austral autumn 1997. Polar Biology 23: 410-419.

Park, Y.H., Charriaud, E. \& Fieux, M. 1998: Thermohaline structure of the Antarctic Surface Water/Winter Water in the Indian sector of the Southern Ocean. Journal of Marine Systems 17: 5-23.

Phillips, H.E. \&. Rintoul, S.R 2000: Eddy variability and energetics from direct current measurements in the Antarctic Circumpolar Current south of Australia. Journal of Physical Oceanography 30: 3050-3076.

Pollard, R.T. \&. Read, J.F. 2001: Circulation pathways and transports of the Southern Ocean in the vicinity of the Southwest 1ndian Ridge. Joumal of Geophysical Research 106: $2881-2898$.

Rintoul S.R., Hughes, C.W. \& Olbers, D. 2001: The Antarctic Circumpolar. Current System 271-302. In Siedler, G, Church, J. \& Gould, J. (eds): Ocean Circulation and Climate- Observing and Modelling the Global Ocean. International Geophysic Series Vol 77, Academic Press, place of publication: $715 \mathrm{pp}$.

Sloyan, B.M. \& Rintoul, S.R. 2001: 'The Southern Ocean Limb of the Deep Overturning Circulation. Journal of Physical Oceanography 31: 143-173.

Smith, V.R. 2002: Climatic change in the Sub-Antarctic: an illustration from Marion Island. Climate Change 52: 345-357.

Swart, S., Speich, S., Ansorge, I.J., Lutjeharms, J.R.E., Gladyshev, S. \& Goni, G. ms: Monitoring the variability of the Antarctic Circumpolar Current south of Africa.

Taylor, H., Gordon, A.L. \& Molinelli, E. 1978: Climatic characteristics of the Antarctic Polar Front Zone. Journal of Geophysical Research 83: 4572-4578.

Weeks, S.J. \& Shillington, F A. 1996: Phytoplankton pigment distribution and frontal structure in the subtropical convergence region south of Africa. Deep-Sea Research I, 43, 5: 739-768. 